\title{
Long-Term Survival of Toxoplasma gondii Sporulated Oocysts in Seawater
}

\author{
Author(s): David S. Lindsay and J. P. Dubey
}

Source: Journal of Parasitology, 95(4):1019-1020. 2009.

Published By: American Society of Parasitologists

DOI: http://dx.doi.org/10.1645/GE-1919.1

URL: http://www.bioone.org/doi/full/10.1645/GE-1919.1

BioOne (www.bioone.org) is a nonprofit, online aggregation of core research in the biological, ecological, and environmental sciences. BioOne provides a sustainable online platform for over 170 journals and books published by nonprofit societies, associations, museums, institutions, and presses.

Your use of this PDF, the BioOne Web site, and all posted and associated content indicates your acceptance of BioOne's Terms of Use, available at www.bioone.org/page/terms_of_use.

Usage of BioOne content is strictly limited to personal, educational, and non-commercial use. Commercial inquiries or rights and permissions requests should be directed to the individual publisher as copyright holder. 


\section{Long-Term Survival of Toxoplasma gondii Sporulated Oocysts in Seawater}

David S. Lindsay and J. P. Dubey ${ }^{\star}$, Center for Molecular Medicine and Infectious Diseases, Department of Biomedical Sciences and Pathology, Virginia-Maryland Regional College of Veterinary Medicine, Virginia Tech, 1410 Prices Fork Road, Blacksburg, Virginia 24061; *United States Department of Agriculture, Agricultural Research Service, Animal and Natural Resources Institute, Building 1001, Building 1001, Beltsville, Maryland 20705. e-mail: lindsayd@vt.edu

ABSTRACT: Toxoplasma gondii is now recognized as an important pathogen in costal marine mammals. Oocysts from cat feces are believed to be washed into seawater and serve as a source of infection via transport hosts. Experimentally, it has been demonstrated that $T$. gondii oocysts can sporulate in seawater and remain infectious for mice for up to 6 mo. The present study examined the long-term survival of $T$. gondii in seawater $(15 \mathrm{ppt} \mathrm{NaCl})$ kept at $4 \mathrm{C}$ or at room temperature. Oocysts kept at $4 \mathrm{C}$ for 24 mo were orally infectious for mice, while those kept at room temperature for 24 mo were not.

Cole et al. (2000) isolated Toxoplasma gondii from sea otters with encephalitis; they hypothesized that oocysts were making their way into the marine environment and that marine mammals were becoming infected by ingesting marine invertebrates, which were acting as phoretic hosts. This hypothesis is now widely accepted (see Conrad et al., 2005). We demonstrated that unsporulated oocysts of $T$. gondii would sporulate in seawater and that these sporulated oocysts were infectious to mice for up to a 6-mo storage in seawater (Lindsay et al., 2003). Lindsay et al. (2001) established that eastern oysters (Crassostrea virginica) could remove $T$. gondii oocysts from seawater and that sporulated $T$. gondii could remain viable in oysters for 85 days (Lindsay et al., 2004). Arkush et al. (2003) showed that mussels (Mytilus galloprovincialis) could remove T. gondii oocysts from seawater; they found that viable oocysts were present in mussels for 3 days and that $T$. gondii DNA could be detected by PCR for up to 21 days after exposure (Arkush et al., 2003). Recently, Miller et al. (2008) detected T. gondii DNA from 1 of 1,396 naturally exposed California mussels (Mytilus califonianus) from Monterey Bay, California. Tissue from this mussel was repeatedly positive by PCR examinations, but it is not known if the oocysts present were infective because animal inoculation was not attempted (Miller et al., 2008). The purpose of the present study was to examine the long-term survival of sporulated $T$. gondii oocysts in seawater kept at $4 \mathrm{C}$ or at room temperature (RT).

Oocysts of $T$. gondii collected from the feces of a cat fed tissues were from a naturally infected chicken from New England (Dubey et al., 2003) and had sporulated in seawater (15 ppt), as previously reported (Lindsay et al., 2003). Oocysts were counted in a hemocytometer, and the volume was adjusted so that $0.5 \mathrm{ml}$ contained $5 \times 10^{5}$ oocysts for the inoculation of mice. Mice were given $T$. gondii oocysts orally using an animal feeding needle. These oocysts were from the same source as those previously demonstrated to be infectious for mice for 6 mo (Lindsay et al., 2003). Groups of 2 CD-1 female mice were housed together and fed a commercial laboratory diet and water, ad libitum. Impression smears were made from the lungs or liver of mice that died, and smears were examined, unstained, for tachyzoites of $T$. gondii. Surviving mice were killed 4-8 wk postinoculation. Their brains were removed, and smears were made from both cerebral hemispheres of the brain and were examined, unstained, for $T$. gondii tissue cysts using a light microscope. The inoculation times poststorage, and the results of inoculations, are presented in Table I.

Oocysts of $T$. gondii remained infectious for mice when stored at $4 \mathrm{C}$ for 24 mo in seawater (Table I). Clinical signs of toxoplasmosis (ruffled hair, labored breathing, lateral recumbence), and deaths, occurred in mice orally inoculated with oocysts that had been stored in seawater at $4 \mathrm{C}$ during the entire study. Mice in all groups, except 1 of 2 mice inoculated with oocysts stored in seawater at $4 \mathrm{C}$ for $15 \mathrm{mo}$, died or were killed because of acute toxoplasmosis. The infectivity of $T$. gondii oocysts kept at RT began to decrease at 15 to 18 mo of storage; both mice inoculated with oocysts stored for 15 mo survived and were clinically normal, and only 1 of 2 mice inoculated with oocysts stored for 18 mo became infected. Toxoplasma gondii oocysts did not survive for 24 mo in seawater kept at RT (Table I). Due to a refrigerator malfunction (freezing of samples), the

DOI: $10.1645 / G E-1919.1$
TABLE I. Protocol and results of time of storage, and temperature, on the infectivity of sporulated Toxoplasma gondii oocysts* for mice.

\begin{tabular}{lcc}
\hline & \multicolumn{2}{c}{ Mice fed oocysts stored at: } \\
\cline { 2 - 3 } Oocysts stored for & $4 \mathrm{C} \dagger$ & Room temperature \\
\hline $1 \mathrm{yr}$ & $2 / 2$ & $2 / 2$ \\
$1 \mathrm{yr} 3 \mathrm{mo}$ & $2 / 2$ & $2 / 2$ \\
$1 \mathrm{yr} 6 \mathrm{mo}$ & $2 / 2$ & $2 / 1$ \\
$2 \mathrm{yr}$ & $2 / 2$ & $2 / 0$ \\
\hline
\end{tabular}

* Oocysts orally administered, $5 \times 10^{5}$.

$\dagger$ Number of mice inoculated/number of mice positive.

infectivity of $T$. gondii oocysts kept in seawater at $4 \mathrm{C}$ could not be evaluated after $2 \mathrm{yr}$.

Limited research has been done on the survival of $T$. gondii in the environment. Frenkel et al. (1975) demonstrated that sporulated T. gondii oocysts in soil could survive for 18 mo. Drinking unfiltered water is a risk factor for obtaining $T$. gondii infections (Bahia-Oliveira et al., 2003), and outbreaks of waterborne infections have been reported (see Dubey, 2004). Dubey (1998) examined the survival of sporulated $T$. gondii oocysts in water under defined conditions. In that study, sporulated $T$. gondii oocysts kept at $4 \mathrm{C}$ were infectious in mice for 54 mo (Dubey, 1998). Oocysts kept in water at $20 \mathrm{C}$ and $25 \mathrm{C}$ did not loose infectivity after 6 mo of storage (Dubey, 1998). Toxoplasma gondii survived in water at RT for $18 \mathrm{mo}$ (Hutchison, 1967).

The present study demonstrates that sporulated $T$. gondii oocysts will survive in seawater for at least $24 \mathrm{mo}$. Additional studies need to be conducted in costal marine environments to determine the phoretic hosts for $T$. gondii in these environments and to determine if $T$. gondii can be isolated from seawater in these locations.

Supported, in part, by grant CA 830573-0101 from the United States Environmental Protection Agency, to D.S.L.

\section{LITERATURE CITED}

Arkush, K. D., M. A. Miller, C. M. Leutenegger, I. A. Gardner, A. E. Packham, A. R. Heckeroth, A. M. Tenter, B. C. Barr, and P. A. ConRad. 2003. Molecular and bioassay-based detection of Toxoplasma gondii oocyst uptake by mussels (Mytilus galloprovincialis). International Journal for Parasitology 33: 10871097.

Bahia-Oliveira, L. M., J. L. Jones, J. Azevedo-Silva, C. C. Alves, F. ORÉFICE, AND D. G. AdDISs. 2003. Highly endemic, waterborne toxoplasmosis in north Rio de Janeiro state, Brazil. Emerging and Infectious Diseases 9: 55-62.

Cole, R. A., D. S. Lindsay, D. K. Howe, C. L. Roderick, J. P. Dubey, N. J. Thomas, And L. A. Baeten. 2000. Biological and molecular characterizations of Toxoplasma gondii strains obtained from southern sea otters (Enhydra lutrisnereis). Journal of Parasitology 86: $526-530$

Conrad, P. A., M. A. Miller, C. Kreuder, E. R. James, J. Mazet, H. Dabritz, D. A. Jessup, F. Gulland, and M. E. Grigg. 2005. Transmission of Toxoplasma: Clues from the study of sea otters as sentinels of Toxoplasma gondii flow into the marine environment. International Journal for Parasitology 35: 1155-1168.

Dubey, J. P. 1998. Toxoplasma gondii oocyst survival under defined temperatures. Journal of Parasitology 84: 862-865. . 2004. Toxoplasmosis-A waterborne zoonosis. Veterinary Parasitology 126: 57-72. 
D. H. Graham, E. Dahl, C. Sreekumar, T. Lehmann, M. F. DAVIS, AND T. Y. Morishita. 2003. Toxoplasma gondii isolates from free-ranging chickens from the United States. Journal of Parasitology 89: $1060-1062$.

Frenkel, J. K., A. Ruiz, and M. Chinchilla. 1975. Soil survival of Toxoplasma oocysts in Kansas and Costa Rica. American Journal of Tropical Medicine and Hygiene 24: 439-443.

Hutchison, W. M. 1967. The nematode transmission of Toxoplasma gondii. Transactions of the Royal Society of Tropical Medicine and Hygiene 61: 80-89.

Lindsay, D. S., M. V. Collins, S. M. Mitchell, R. A. Cole, G. J. Flick, C. N. Wetch, A. Lindquist, and J. P. Dubey. 2003. Sporulation and survival of Toxoplasma gondii oocysts in seawater. Journal of Eukaryotic Microbiology 50 (Suppl.): S687-S688.
C. N. Wetch, A. C. Rosypal, G. J. Flick, A. M. Zajac, A. Lindeuist, and J. P. Dubey. 2004. Survival of Toxoplasma gondii oocysts in eastern oysters (Crassostrea virginica). Journal of Parasitology 90: 1054-1057.

, K. K. Phelps, S. A. Smith, G. Flick, S. S. Sumner, and J. P. Dubey. 2001. Removal of Toxoplasma gondii oocysts from sea water by eastern oysters (Crassostrea virginica). Journal of Eukaryotic Microbiology 48 (Suppl.): 197S-198S.

Miller, M. A., W. A. Miller, P. A. Conrad, E. R. James, A. C. Melli, C. M. Leutenegger, H. A. Dabritz, A. E. Packham, D. Paradies, M. Harris et Al. 2008. Type X Toxoplasma gondii in a wild mussel and terrestrial carnivores from coastal California: New linkages between terrestrial mammals, runoff and toxoplasmosis of sea otters. International Journal for Parasitology 38: 1319-1328. 